Article

\title{
Temporal Changes in Air Quality during a Festival Season in Kannur, India
}

\author{
Resmi CT ${ }^{1}$, Nishanth $\mathrm{T}^{2, * \mathbb{D}}$, Satheesh Kumar $\mathrm{MK}^{3}$, Balachandramohan $\mathrm{M}^{1}$ and Valsaraj $\mathrm{KT}^{4}$ \\ 1 Department of Physics, Erode Arts and Science College, Affiliated to Bharathiar University, \\ Tamil Nadu 638009, India; ctresmi816@gmail.com (R.C.); balamohan2006@gmail.com (B.M.) \\ 2 Department of Physics, Sree Krishna College Guruvayur, Affiliated to University of Calicut, \\ Kerala 680102, India \\ 3 Department of Atomic and Molecular Physics, Manipal University, Karnataka 576104, India; \\ drmksatheesh@gmail.com \\ 4 Cain Department of Chemical Engineering, Louisiana State University, Baton Rouge, LA 70803, USA; \\ valsaraj@lsu.edu \\ * Correspondence: nisthu.t@gmail.com
}

Received: 16 February 2019; Accepted: 8 March 2019; Published: 13 March 2019

check for updates

\begin{abstract}
This study looked at the variation in air quality during the periods of fireworks as assessed from the change in ambient concentrations of air pollutants like particulate matter $\left(\mathrm{PM}_{10}\right), \mathrm{O}_{3}$, and $\mathrm{NO}_{2}$ for pre-, post-, and Vishu days for four consecutive years in 2015, 2016, 2017, and 2018 in Kannur, India. Enhanced levels of $\mathrm{O}_{3}, \mathrm{NO}_{2}, \mathrm{NO}$, and $\mathrm{PM}_{10}$ were observed during the intense usage of fireworks. The concentration of metals in $\mathrm{PM}_{10}$ increased and the percent increase was found to be different for metal traces. A pronounced increase in the aerosol optical depth (AOD) in the lower wavelength region of solar radiation reveals the abundance of fine mode particles. The concentrations of $\mathrm{O}_{3}$ and $\mathrm{NO}_{2}$ were observed to increase by more than $100 \%$ on Vishu day than the control days for the observational period. Simulation using the National Center for Atmospheric Research (NCAR) Master Mechanism photochemical box model indicates a more than $100 \%$ enhancement in $\mathrm{NO}_{2}$ photolysis rates during the fireworks episode, which leads to a $100 \%$ increase in the surface ozone production. Observations as well as model simulations indicate that the enhanced photochemical ozone production from $\mathrm{NO}_{2}$ photolysis is possibly the main driver of ozone production during the Vishu at this site. The air quality index (AQI) revealed the deterioration of air quality at the observational site during the period of Vishu.
\end{abstract}

Keywords: Kannur; fireworks; trace gases; air quality; box model

\section{Introduction}

Air pollution, whether by toxic chemicals or biological materials, severely affects human health [1,2]. Air quality can deteriorate through short-term polluting events and there are several studies of such events and their health effects [3-14]. The burning of fireworks during festivals has been sporadic, but contributes high loading of the atmosphere with air pollutants. The burning of fireworks at a high temperature releases dense smoke of carbonaceous gases, nitrous oxides, sulphur compounds, and particles of metal oxides [15-20]. Among the Indian festivals, Diwali is a national festival in India celebrated during October-November with coordinated fireworks. The impact of fireworks on the air quality deterioration has been examined at various Indian locations [21-25]. These studies revealed that continuous fireworks displays over extended periods of time released extensive amounts of toxic metal fumes and gases like carbon dioxide $(\mathrm{CO})$, sulphur dioxide $\left(\mathrm{SO}_{2}\right)$, and nitrogen dioxide $\left(\mathrm{NO}_{2}\right)$, as well as particulate matter (PM), into the atmosphere [26,27]. The impact of air pollution caused by fireworks is well recognized [28,29], and is not confined to India [30-32]. 
The research was focused on the impact of trace gases and particulate matter [33-36] to explore their influence on atmospheric dynamics and on the health impacts of trace metals released from these intense fireworks [8,37-39]. $\mathrm{PM}_{10}$ contains trace elements such as $\mathrm{As}, \mathrm{Cd}, \mathrm{Co}, \mathrm{Cr}, \mathrm{Ni}, \mathrm{Pb}$, and Se, which are harmful to human beings and animals even in trace amounts [40]. Inhalation of particles emitted from fireworks displays can cause injurious effects on human health, especially to children and the aged [41-47]. During the festival days, increases in the concentrations of air pollutants as well as toxic species such as PM, black carbon (BC) aerosols, and greenhouse gases have been monitored at different sites in India [26,39,48-51].

Kerala is a coastal state in south India blessed with natural beauty, lush tropical vegetation, and a moderate climate. Air pollution is an emerging issue in the state of Kerala because of increasing industrial and vehicular emissions [52,53]. There are also episodic emissions resulting from various social festival activities unique to this state. Vishu is the zodiac New Year in Kerala and is observed on the first day of the Malayalam month of 'Medam' in the Malayalam calendar, which usually coincides with April. Crackers and sparklers are burnt mainly on the day of Vishu to mark the beginning of the year and also on the day before. Continuous fireworks are set off from 17:00 to 22:00 (IST) on the eve of Vishu on 14 April and early morning from 04:00 to 07:00 (IST) the following day, 15 April. Furthermore, the fireworks occur mainly at night when the shallow boundary layer exacerbates the air quality. The pollutants emitted from fireworks can stay in the atmosphere for a long time and accumulate near the surface during the night time because of the decrease in boundary layer height due to low temperature favored by lower wind speed [39,50].

The main objective of this study is to assess the short-term variation in the ambient concentration of surface $\mathrm{O}_{3}, \mathrm{NO}_{2}, \mathrm{PM}_{10}$, and spectral variations in aerosol optical depth (AOD) linked with firework events at Kannur during Vishu festival for four consecutive years in 2015, 2016, 2017, and 2018. The enhancement of $\mathrm{O}_{3}$ and $\mathrm{NO}_{2}$ observed during the fire bursting episode is validated by National Center for Atmospheric Research (NCAR) Master Mechanism photochemical box model. Furthermore, the research includes a quantitative analysis of metal concentrations present in particulate matter and the rate of change of $\mathrm{O}_{3}$ on a diurnal scale during fire bursting episodes. In addition, it also aims calculate the air quality index over Kannur during Vishu to categorize it according to the pollution load.

\section{Methods}

\subsection{Observational Site and General Meteorology}

The impact of firecrackers on the air quality over Kannur district in North Kerala was carried out at the Kannur University Campus (KUC) $\left(11.9^{\circ} \mathrm{N}, 75.4^{\circ} \mathrm{E}\right)$, situated $15 \mathrm{~km}$ north from Kannur town.

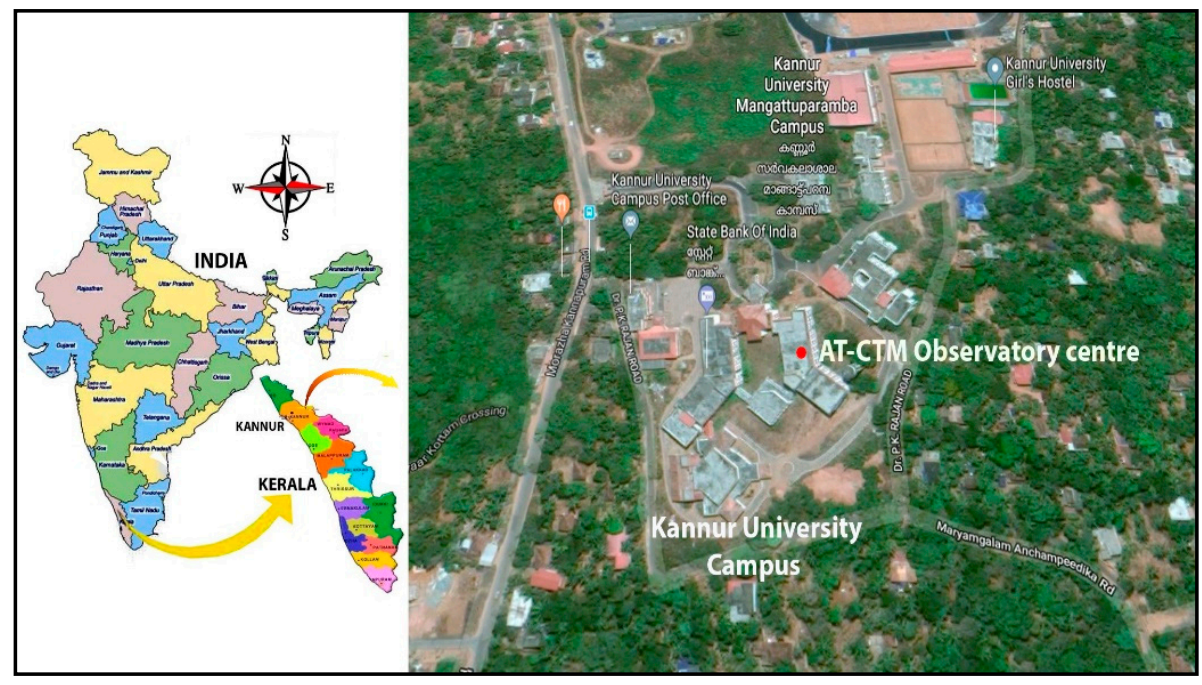

Figure 1. Location of observation site. 
The observational site is situated $1 \mathrm{~km}$ away from the National Highway (NH 17) and $6 \mathrm{~km}$ away from the Arabian Sea and is surrounded by a densely populated residential area. Figure 1 shows the geographical location of the observational site situated at Kannur University Campus and its surroundings.

The meteorological parameters like temperature, relative humidity, wind speed, and wind direction were acquired from the local automatic weather station run by the Meteorological and Oceanographic Satellite Data Archival Centre (MOSDAC) established by the Indian Space Research Organization (ISRO). The meteorological parameters were recorded on an hourly basis during the period of observations and it is evident that the atmospheric condition remained unaltered as far as these parameters were concerned. During the monitoring period, the sky remained clear with a few scattered clouds. A maximum daytime temperature of $37.1 \pm 1.5{ }^{\circ} \mathrm{C}$ at 15:00 and a minimum temperature of $27.5 \pm 1.6{ }^{\circ} \mathrm{C}$ at 04:00 were observed on Vishu day. During the control days, the maximum and minimum average temperatures were $36.2 \pm 1.8{ }^{\circ} \mathrm{C}$ and $26.8 \pm 1.8{ }^{\circ} \mathrm{C}$, respectively. The maximum humidity of $79.2 \% \pm 2.9 \%$ at midnight and minimum of $66.2 \% \pm 3.2 \%$ at 15:00 in the afternoon on Vishu day were observed. The maximum and minimum average values of relative humidity observed during control days were $78.5 \% \pm 2.6 \%$ and $65.9 \% \pm 2.2 \%$, respectively. The average wind speed ranged from $2 \mathrm{~ms}^{-1}$ to $5.2 \mathrm{~ms}^{-1}$ confined in the northwest direction. As the wind speed remains unaltered, the transport of pollutants by advection is likely not affected during the fireworks.

\subsection{Observation of Trace Gases and $A O D$}

Variations in air quality have been investigated during the fireworks associated with Vishu festival on 14 and 15 April for the years 2015, 2016, 2017, and 2018 from the measured concentrations of surface $\mathrm{O}_{3}, \mathrm{NOx}\left(\mathrm{NO}+\mathrm{NO}_{2}\right)$, and $\mathrm{PM}_{10}$ since 2009 at the Kannur University Campus. $\mathrm{O}_{3}$ present in the ambient air has been measured using the analyser, which works on the principle of strong absorption of $\mathrm{UV}$ radiation at $253.7 \mathrm{~nm}$ by $\mathrm{O}_{3}$ molecules. The concentrations of $\mathrm{O}_{3}$ and $\mathrm{NOx}\left(\mathrm{NO}+\mathrm{NO}_{2}\right)$ have been continuously monitored since November 2009 at the Kannur University Campus, in which $\mathrm{O}_{3}$ and NOx mixing ratios have been successfully measured with the aid of ground based gas analysers from Environment SA, France. The analyser incorporates corrections owing to changes in temperature and pressure in the absorption cell and drift in the intensity of the UV lamp. A hand-held sun photometer was used for direct retrieval of spectral AOD in a column of the atmosphere. In this study, a MICROTOPS II (Microprocessor Controlled Total $\mathrm{O}_{3}$ Portable Spectrometer) fitted with narrow-band interference filters is employed to estimate the AODs at wavelengths of $340 \mathrm{~nm}, 440 \mathrm{~nm}, 675 \mathrm{~nm}$, $870 \mathrm{~nm}$, and $1020 \mathrm{~nm}$. The extinction of solar radiation by aerosols strongly depends on the size of the particles and the wavelength interval. The details of the sun photometer and the measuring technique have been described by Morys et al. [54].

\subsection{Quantitative Analysis of Particulate Matter}

A Respirable Dust High Volume Air Sampler (ENVIROTECH, India Model APM 460 NL) was placed on top of the building at a height of $10 \mathrm{~m}$ from the ground to collect dust particles that are less than $\mathrm{PM}_{10}$ present in the ambient air during the period 11 to 18 April for the years 2015, 2016, 2017, and 2018. The sampler used an improved cyclone (with a cut off D50 at 10 microns) to separate the coarser particles (>10 microns) from the air stream before filtering it on a glass microfiber filter. The built-in manometer provided a precise flow rate of air through the filter. The timer attached to this sampler accurately measured the duration of airflow through the filter. Earlier, we studied the influence of $\mathrm{O}_{3}$ precursors and particulate matter on the variation of surface $\mathrm{O}_{3}$ over this location using this set up [55]. Nitric acid was used to digest the filters collecting $\mathrm{PM}_{10}$ on a hot plate. For each sample, the digestion continued to reduce the final volume of the sample to $3 \mathrm{~mL}$. It was then filtered using filter paper and the filtrate was diluted using double distilled water to $25 \mathrm{~mL}$. The filtrate was 
then examined to identify the concentrations of $\mathrm{Na}, \mathrm{Hg}, \mathrm{Cd}, \mathrm{Cu}, \mathrm{Pb}, \mathrm{Ba}, \mathrm{Ca}, \mathrm{Fe}$, and $\mathrm{Zn}$ using an atomic absorption spectrophotometer.

\section{Model Description}

NCAR-Tropospheric Ultra Violet Visible (TUV) and Master Mechanism (MM) Model

The National Center for Atmospheric Research (NCAR) tropospheric ultra violet visible (TUV) radiative transfer model is a cloud free model [56] developed to simulate the actinic flux at a given location $[57,58]$. The TUV module was initialized with measured values as latitude, longitude, aerosol optical depth, alpha, single scattering albedo, total columnar $\mathrm{O}_{3}$, columnar $\mathrm{NO}_{2}$, columnar $\mathrm{SO}_{2}$, and surface albedo to commutate the photolysis rates. The model is suggested for the calculation of UV spectral irradiance on the Earth's surface. The model also estimates photolysis rate coefficients of trace gases at $0.5 \mathrm{~km}$ above sea level; wavelength range is $121-735 \mathrm{~nm}$ in 156 non-equally spaced intervals [59]. The TUV module scans the selected reaction subset for photolysis reactions and uses quantum yields to calculate photolysis rate coefficients in a $121-735 \mathrm{~nm}$ wavelength range. The module was updated with cross section and quantum yields from recent evaluations for inorganic species [60] and organic species [61]. Environmental conditions opted for the model simulations are listed in Table 1.

Table 1. Environmental conditions opted for simulations. AOD-aerosol optical depth.

\begin{tabular}{cc}
\hline Parameters & Values \\
\hline Latitude & $11.9^{\circ} \mathrm{N}$ \\
\hline Longitude & $75.4^{\circ} \mathrm{E}$ \\
\hline Time Zone & 5.5 \\
\hline Temperature & $305 \mathrm{~K}$ \\
\hline Air Number Density & $72 \%$ \\
\hline Relative Humidity & 0.10 \\
\hline Surface Albedo & $5 \mathrm{molecules} / \mathrm{cm}^{3}$ \\
\hline Parcel Elevation & $265 \mathrm{DU}(\mathrm{OMI})$ \\
\hline Overhead O 3 Column & 0.5 \\
\hline AOD at 550 nm & 1 \\
\hline Aerosol Angstrom Coefficient & 0.72 \\
\hline Aerosol Single Scattering Albedo & \\
\hline
\end{tabular}

NCAR Master Mechanism (NCAR-MM), a chemical box model (zero dimension), developed at National Centre for Atmospheric Research, Boulder, USA, was used to simulate the diurnal variation of $\mathrm{O}_{3}$, initialized with ground based measurements at the observational site. This model computes the time dependent chemical evolution of an air parcel, taking into account the detailed gas phase chemistry. The detailed gas phase chemistry consists of 5000 reactions among the 2000 species [62]. The NCAR-MM box model was initiated with 12 trace species $\left(\mathrm{O}_{3}, \mathrm{H}_{2} \mathrm{O}, \mathrm{CO}, \mathrm{CH}_{4}, \mathrm{NO}, \mathrm{NO}_{2}, \mathrm{OH}, \mathrm{HO}_{2}\right.$, $\mathrm{CH}_{2} \mathrm{O}, \mathrm{C}_{3} \mathrm{H}_{6}$, isoprene, i-butane), while $\mathrm{N}_{2}, \mathrm{O}_{2}, \mathrm{M}$ (carrier gas), and photon energy were hard-wired in the model.

On the basis of these species, 1031 reactions were used in the simulation. The model also estimates deposition first order rate constants. This model cannot be substituted for a full 3D chemistry-transport model, predominantly for the spatial and temporal distribution of urban emissions, and the vertical and horizontal transport and dispersion from the city. The details of the NCAR-MM model have been described by Madronich [63]. The environmental parameters used for the box model simulation are shown in Table 2. 
Table 2. Environmental parameters opted for the box model simulations.

\begin{tabular}{cc}
\hline Parameter & Values \\
\hline Latitude & $11.9^{\circ} \mathrm{N}$ \\
\hline Longitude & $75.4^{\circ} \mathrm{E}$ \\
\hline Temperature & $308 \mathrm{~K}$ \\
\hline Relative Humidity & $66 \%$ \\
\hline Ozone Column & $360 \mathrm{DU}(\mathrm{OMI})$ \\
\hline AOD at 550 $\mathrm{nm}$ & 0.52 \\
\hline Aerosol SSA & 0.72 \\
\hline Aerosol Angstrom Coefficient & 0.88 \\
\hline
\end{tabular}

\section{Results and Discussions}

\subsection{Observation of Aerosol Optical Depth during Vishu Festival}

Mass concentrations of particulate matter were found to be increased during firework episodes owing to their heavy loading in the atmosphere [33]. As AOD $(\tau)$ has a strong dependence on the wavelength $(\lambda)$ of radiation and is frequently parameterized by the Angstrom exponent $\alpha$ [64], the extinction law used for connecting $\tau$ and $\lambda$ is

$$
\tau_{\alpha \lambda}=\beta \lambda^{-\alpha}
$$

The wavelength exponent $\alpha$ describes the spectral behaviour of the optical depth and $\beta$ is a measure of the vertical column burden of aerosols and becomes equal to $\tau$ for $\lambda=1 \mu \mathrm{m}$. Values of $\alpha \leq 1$ indicate size distribution dominated by coarse mode aerosols that are typically associated with the dust and sea salt, and values of $\alpha \geq 2$ indicate size distribution dominated by fine mode aerosols produced from urban pollution and biomass burning $[65,66]$.

The unique feature of our investigation is the presence of higher values of AODs observed in April than in other months, owing to the region's festival events followed by festivals in this region. An analysis of the results further reveals an abrupt change in AOD and Angstrom size parameter $(\alpha$ and $\beta$ ) values with the burning of firecrackers associated with the Vishu festival. Figure 2 shows the mean AOD values for different wavelengths from 9 to 13 April (Pre Vishu), 14 and 15 April (Vishu Day), and 16 to 19 April (Post Vishu) of the years 2015, 2016, 2017, and 2018.

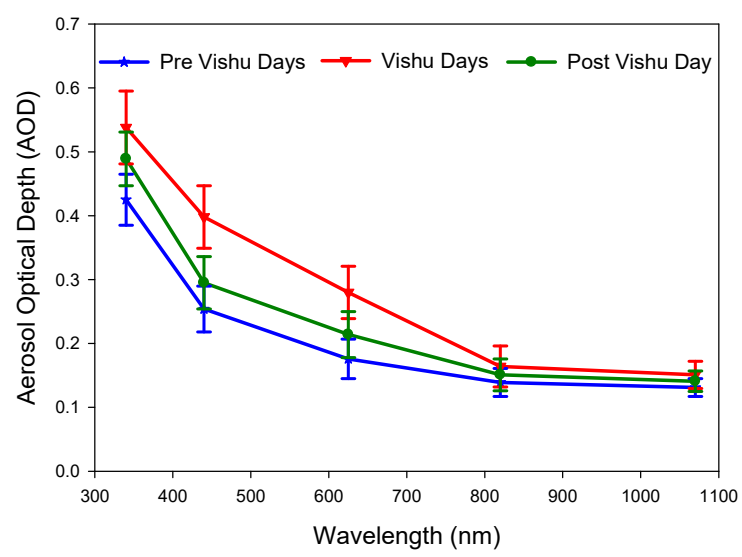

Figure 2. Variation of the mean aerosol optical depth (AOD) (over 2015-2018) on pre-, post-, and Vishu day for different wavelengths. The vertical bar in the graph represents one sigma standard deviation. Mean values of AOD for $340 \mathrm{~nm}, 440 \mathrm{~nm}, 625 \mathrm{~nm}, 820 \mathrm{~nm}$, and $1070 \mathrm{~nm}$ on Vishu day are $0.538 \pm 0.570$, $0.398 \pm 0.490,0.280 \pm 0.410,0.164 \pm 0.321$, and $0.151 \pm 0.212$, respectively. 
The increase in AOD is found to be much higher at low wavelength regions than at high wavelength regions, indicating the distinct abundance of fine mode particles on the day of the fireworks. A decline in spectral AOD values in the pre-, post-, and Vishu days is observed and this shows severe loading of particles because of firecrackers. The higher AODs in the morning may be caused by a surface temperature inversion, which traps air pollutants within a shallow air layer, thus increasing their concentration [67]. An increase in particle size may be related to ageing of the aerosol, with associated changes in size distribution because of coagulation, condensation, and gas-to-particle conversion. Generally, the $\alpha$ exponent exhibited higher values in the early morning and early afternoon with a decrease around midday; this might be caused by surface heating, which produced a decrease in the surface moisture content and masked surface humidity-induced scattering effects at longer wavelengths, thus reducing $\alpha$.

The variation of AOD and particle size distribution before and after Vishu festival was analysed using a second order polynomial fit in the $\log \lambda$ versus $\log \tau$ graph. To investigate the abundance of coarse and fine particles in the particulate matter, bimodal distribution of AOD is usually used, which is quite clear from Junge's law [68]. The size distribution of aerosols does not typically follow the Junge's law, but rather exhibits a bimodal distribution so that a second order polynomial fit exists between $\ln \tau$ and $\ln \lambda$ data, which provides a better correlation with the measured AOD.

The positive curvature in the pre-phase in Figure $3 a$ and the negative curvature in the post-phase in Figure $3 \mathrm{~b}$ indicate the dominant fingerprints of the fine mode aerosols produced from the burning of crackers [69]. These figures support our assumption that under highly turbid atmospheres, the wavelength dependence of the $\alpha$ values is less significant and the $\ln \tau$ versus $\ln \lambda$ curve approaches linearity. The linear fit depends strongly on atmospheric conditions, exhibiting significant uncertainties under low turbidities. The curvature of $\ln \tau$ versus $\ln \lambda$ depends strongly on atmospheric conditions and the Angstrom exponent. It becomes lower as the atmosphere tends to be turbid and has negative correlation (0.21) values. It is observed that aerosol size had a great influence on $\alpha$ values. A linear fit of $\ln \tau$ versus $\ln \lambda$ yielded significant differences from the measured AODs.
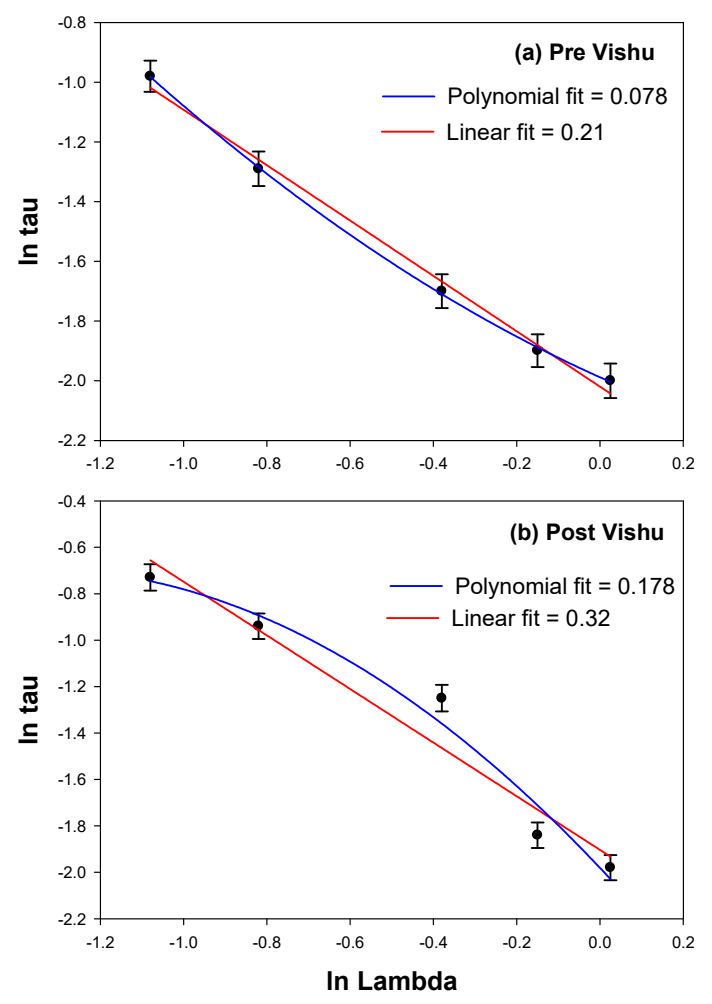

Figure 3. (a) $\ln \lambda$ vs. $\ln \tau$ for pre-Vishu and (b) $\ln \lambda$ vs. $\ln \tau$ for post-Vishu for the years 2015, 2016, 2017, and 2018. The vertical bar in the graph represents one sigma standard deviation. 
The negative curvature in the $\log \lambda$ versus $\log \tau$ graph in Figure $3 b$ indicates the presence of an extensive amount of fine mode aerosols in the atmosphere [70] in April-May and the positive curvature represents the presence of coarse mode particles. $\ln \lambda$ versus $\ln \tau$ for the pre-Vishu norm of residuals for the linear fit is 0.21 and for the polynomial fit is 0.078 , whereas in the case of post-Vishu, the norm of residuals for the linear fit is 0.28 and for the polynomial fit is 0.18 . The Student's $t$-test value and one-tailed $p$-value indicate that the increase is statistically significant at a $95 \%$ confidence level at the lower wavelength region. The higher value of coefficient of variation (standard deviation/mean) indicates that the aerosol variability is more pronounced in the post-Vishu period. Several studies [71-74] have concluded that $\alpha$ values vary significantly according to the type of aerosols and the wavelength interval used for the determination.

\subsection{Quantitative Analysis of Metal Concentrations Present in $P M_{10}$}

The concentration of particulate matter in ambient air was estimated from the ratio of net mass collected in the volume of air sampled. Figure 4 shows the $\mathrm{PM}_{10}$ variation for $24 \mathrm{~h}$ (08:00 to 08:00) during the Vishu festival days for the years 2015, 2016, 2017, and 2018. From the graph, it is evident that the particle loading was much higher on 14 and 15 April compared with the control days of 11 , $12,13,16,17$, and 18 April. The $24 \mathrm{~h}$ average concentration of $\mathrm{PM}_{10}$ increased to $195 \mu \mathrm{g} / \mathrm{m}^{3}$ from $88 \mu \mathrm{g} / \mathrm{m}^{3}$ on 15 April. According to the Central Pollution Control Board (CPCB) of India, the national ambient air quality standards for $\mathrm{PM}_{10}$ for $24 \mathrm{~h}$ concentration in residential areas is $100 \mu \mathrm{g} / \mathrm{m}^{3}$.

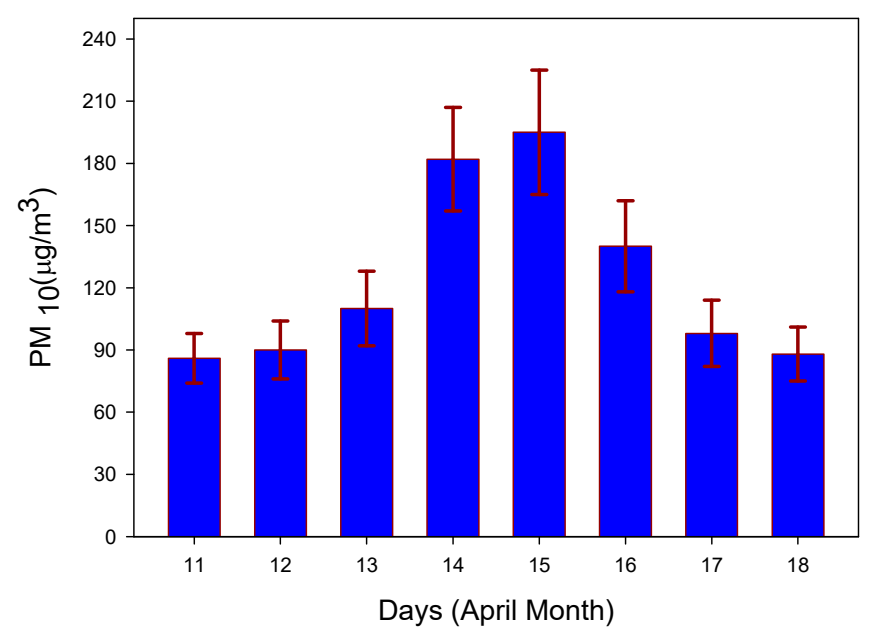

Figure 4. Variation of $\mathrm{PM}_{10}(24 \mathrm{~h})$ concentration during pre-, post-, and Vishu days. PM-particulate matter.

The metal analyses for $\mathrm{Na}, \mathrm{Hg}, \mathrm{Cu}, \mathrm{Pb}, \mathrm{Ba}, \mathrm{Ca}, \mathrm{Fe}$, and $\mathrm{Zn}$ were carried out from $\mathrm{PM}_{10}$ samples collected on the pre-Vishu day (13 April), Vishu day (15 April), and post-Vishu day (17 April) for $24 \mathrm{~h}$ during the study period. The identified concentrations of the eight metals for $24 \mathrm{~h}$ (08:00 to 08:00) on pre-, post-, and Vishu days for three continuous years are shown in Table 3. The table clearly indicates the enhanced metal concentration in the ambient air, which in turn reduces the air quality. The concentrations of metals in present $\mathrm{PM}_{10}$ was found to have increased and the percentage of increase varied from metal to metal. In this study, a dramatic increase was observed in $\mathrm{Hg}(366.67 \%)$, $\mathrm{Cu}(225 \%), \mathrm{Ca}(183.93 \%), \mathrm{Pb}(171.19 \%), \mathrm{Na}(145.90 \%), \mathrm{Ba}(137.50 \%), \mathrm{Zn}(97.22 \%)$, and $\mathrm{Fe}(89.58 \%)$. One of the significant observations was the enhanced amount of mercury present in the ambient air, which is a serious concern owing to its high toxicity. Barium was found in huge quantities in the firework debris followed by lead and copper, and their observed quantities were about three times higher than those on the normal days, indicating that the ambient air was contaminated with fine particles of barium, lead, and copper salt compounds used in the fireworks. The concentration of metals estimated on pre-Vishu days was not sourced from the fireworks and was attributed to the 
normal concentration of metals in the atmosphere of Kannur. The chemical analysis of the $\mathrm{PM}_{10}$ sample on the Vishu day shows that the metal concentrations were relatively higher on the day of the fireworks.

Table 3. Twenty-four hour average concentrations of different metals in ambient air of Kannur during pre-, post-, and Vishu days for the years 2015, 2016, 2017, and 2018.

\begin{tabular}{|c|c|c|c|c|c|c|c|}
\hline \multirow{3}{*}{ Metals } & \multicolumn{6}{|c|}{ Concentrations $\left(\mu \mathrm{g} / \mathrm{m}^{3}\right)$} & \multirow{3}{*}{$\begin{array}{c}\text { Average } \% \text { of Increase of } \\
\text { Metal Concentration on } \\
\text { Vishu Day }\end{array}$} \\
\hline & \multicolumn{2}{|c|}{$\begin{array}{c}13 \text { April } \\
\text { (Pre Vishu) }\end{array}$} & \multicolumn{2}{|c|}{$\begin{array}{l}15 \text { April } \\
\text { (Vishu) }\end{array}$} & \multicolumn{2}{|c|}{$\begin{array}{c}17 \text { April } \\
\text { (Post Vishu) }\end{array}$} & \\
\hline & Avg. & Std. dev & Avg. & Std. dev & Avg. & Std. dev & \\
\hline $\mathrm{Na}$ & 0.61 & 0.14 & 1.50 & 0.21 & 0.74 & 0.08 & 145.90 \\
\hline $\mathrm{Hg}$ & 0.06 & 0.03 & 0.28 & 0.11 & 0.08 & 0.01 & 366.67 \\
\hline $\mathrm{Cu}$ & 8.00 & 1.76 & 26.0 & 2.52 & 11.0 & 1.95 & 225.00 \\
\hline $\mathrm{Pb}$ & 11.8 & 1.03 & 32.0 & 2.43 & 13.0 & 1.45 & 171.19 \\
\hline $\mathrm{Ba}$ & 16.0 & 1.50 & 38.0 & 4.31 & 22.0 & 1.60 & 137.50 \\
\hline $\mathrm{Ca}$ & 1.12 & 0.16 & 3.18 & 0.60 & 1.32 & 0.40 & 183.93 \\
\hline $\mathrm{Fe}$ & 0.48 & 0.12 & 0.91 & 0.36 & 0.54 & 0.15 & 89.58 \\
\hline $\mathrm{Zn}$ & 0.36 & 0.09 & 0.71 & 0.20 & 0.41 & 0.11 & 97.22 \\
\hline
\end{tabular}

\subsection{Variation of Surface Ozone and $\mathrm{NO}_{2}$ during Fireworks}

Surface ozone $\left(\mathrm{O}_{3}\right)$ is mainly produced by photochemical reactions affecting various anthropogenic pollutants and is considered as a natural greenhouse gas as well as an important secondary air pollutant with damaging impacts on human health, crops, and vegetation [75]. Only limited studies have been reported on the enhancement of surface $\mathrm{O}_{3}[49,76]$ and $\mathrm{NO}_{2}[8,37,44,77]$ during fireworks in India. The day and night time $\mathrm{O}_{3}$ concentrations on Vishu day showed a significant increase from 18:00 to 22:00 and 04:00 to 10:00 (IST), marked by intense fireworks burning over the observational site. Figure 5 shows the diurnal variation of surface $\mathrm{O}_{3}$ at Kannur, which shows a sharp increase in $\mathrm{O}_{3}$ concentration during the night time of 14 April and the day of 15 April for four consecutive years of 2015,2016, 2017, and 2018. Observed $\mathrm{O}_{3}$ concentration increased from its value of $\sim 9.6 \mathrm{ppbv}$ just after the fire bursting to $\sim 16.2 \mathrm{ppbv}$ (increase of $69 \%$ ) on 14 April (evening spell) and from $\sim 4.6 \mathrm{ppbv}$ just after the fire bursting to $\sim 9.8 \mathrm{ppbv}$ (113\%) on 15 April near (early morning spell) with the net upsurge in $\mathrm{O}_{3}$ levels of $6.6 \mathrm{ppbv}$ and $5.2 \mathrm{ppbv}$, respectively, for the year 2017. This sporadic enhancement of $\mathrm{O}_{3}$ concentration is well matched with the two spells of intense fire bursting events. This may be the result of an increase in $\mathrm{NO}_{2}$ emission and increased fire bursting in 2018 compared with previous years. The $\mathrm{O}_{3}$ concentration during Vishu was found to be higher in 2018 than in 2017, 2016, and 2015. This may be caused by an increase in $\mathrm{NO}_{2}$ emission and increased fire bursting in 2018, greater than that in 2017, 2016, and 2015. A similar trend in $\mathrm{O}_{3}$ enhancement during Diwali was observed by Swamy et al. [50] at Hyderabad.

Figure 6 shows the diurnal variation of $\mathrm{NO}_{2}$ at Kannur, which shows a sharp increase in the night time of 14 April and the day time on 15 April for the four consecutive years.

It is clear that the increase in $\mathrm{NO}_{2}$ resulted from the intense fireworks and its periodic increases are attributed to the two spells of fire bursting. This enhancement in the $\mathrm{NO}_{2}$ concentrations during the fire bursting is the main reason for the enhancement in the production of $\mathrm{O}_{3}$ over the observational site [49]. The observed $\mathrm{NO}_{2}$ concentration increased from its value of $\sim 3.1 \mathrm{ppbv}$ just after the fire bursting to $\sim 6.3 \mathrm{ppbv}$ (increase of 103\%) on 14 April (evening spell) and from $\sim 3.1 \mathrm{ppbv}$ just after the fire bursting to $\sim 5.7 \mathrm{ppbv}$ (85\%) on 15 April near (early morning spell) with the net increase in $\mathrm{NO}_{2}$ levels of $3.2 \mathrm{ppbv}$ and $2.6 \mathrm{ppbv}$, respectively, for the year 2018, which shows a higher concentration value of $\mathrm{NO}_{2}$ than previous years. A huge amount of fine mode soot and various metal oxides particles 
emitted into the atmosphere could catalyse atmospheric chemical reactions [78]. Figure 7 shows the correlation between surface $\mathrm{O}_{3}$ and $\mathrm{NO}_{2}$ concentrations during the night of Vishu days of the years 2015-2018.
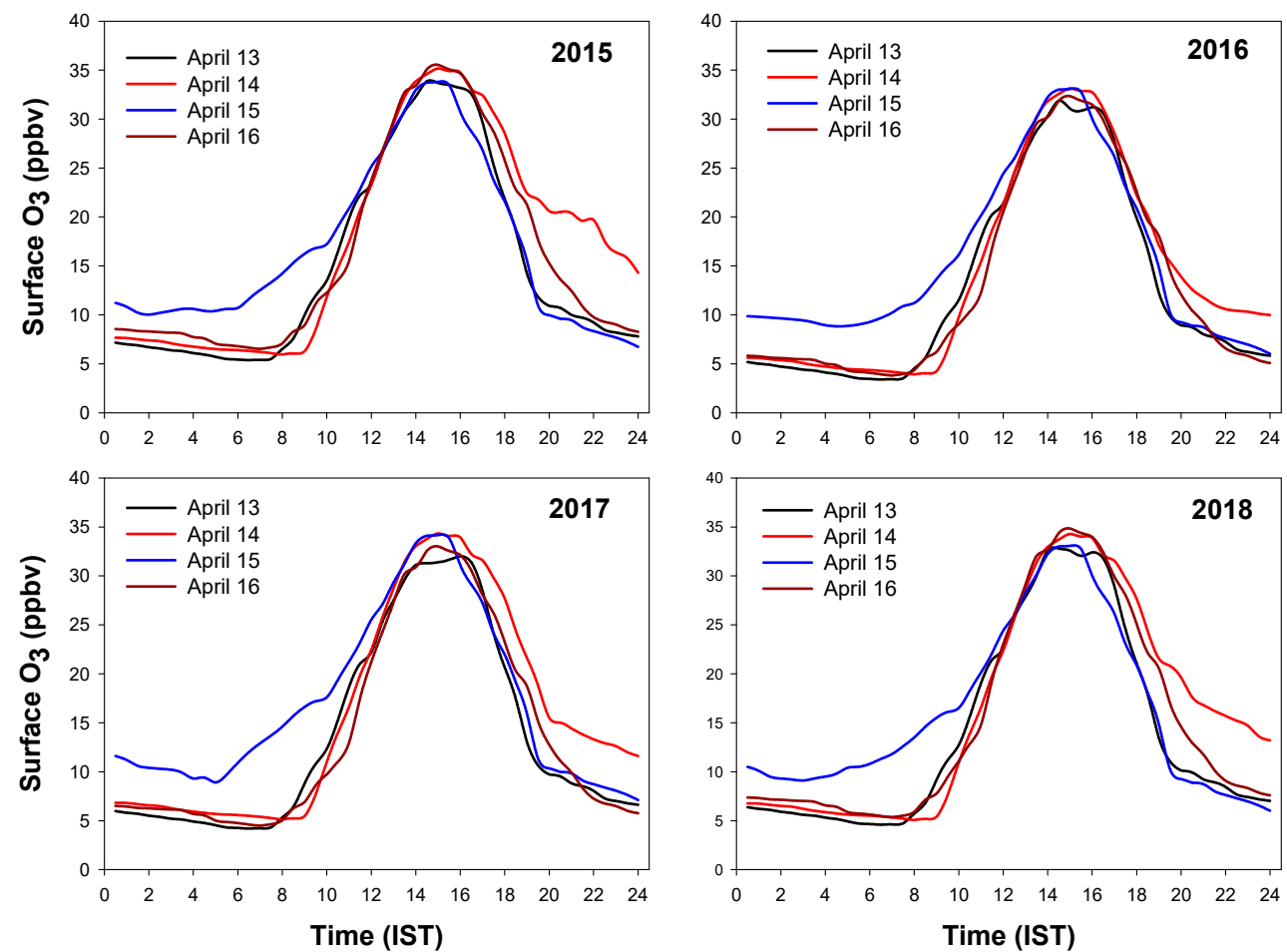

Figure 5. Diurnal variation of surface $\mathrm{O}_{3}$ at Kannur during pre-, post-, and Vishu days for four consecutive years of 2015, 2016, 2017, and 2018.
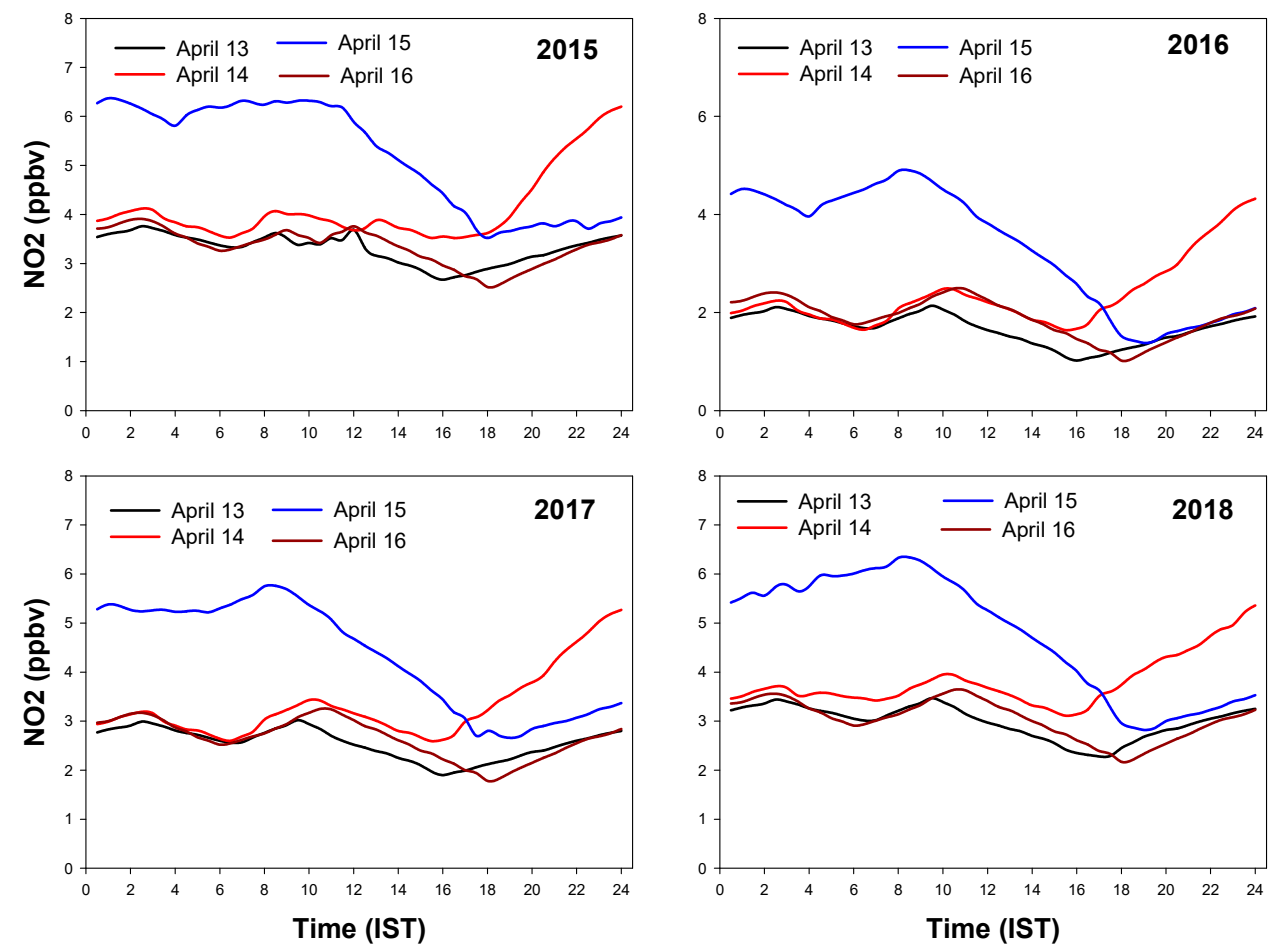

Figure 6. Diurnal variation of $\mathrm{NO}_{2}$ at Kannur during pre-, post-, and Vishu days for four consecutive years of 2015, 2016, 2017, and 2018. 


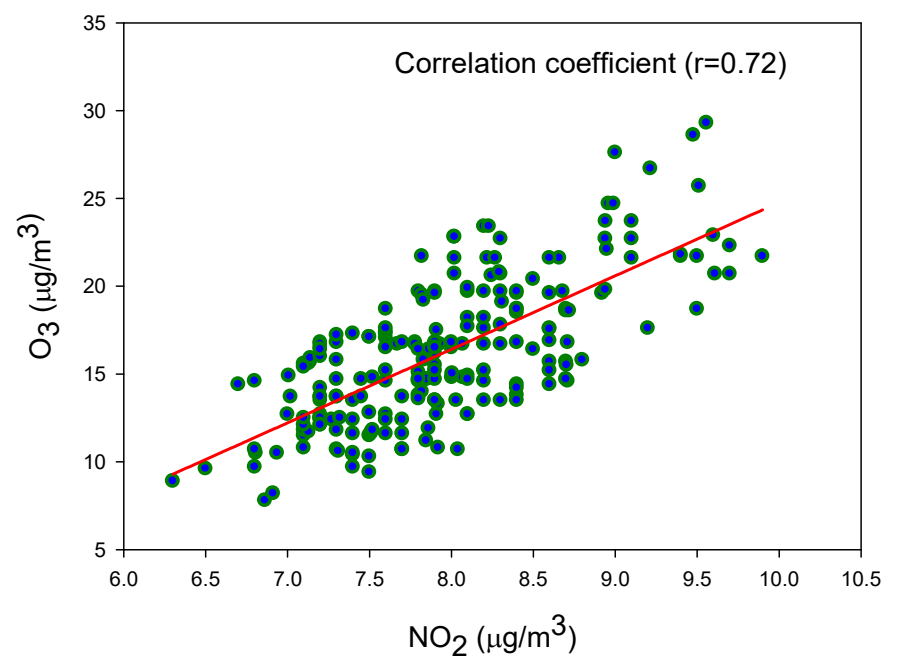

Figure 7. Correlation between $\mathrm{O}_{3}$ and $\mathrm{NO}_{2}$ during the night time in Vishu.

From the figure, it is clear that this linear relation (with a correlation coefficient 0.72) between $\mathrm{O}_{3}$ and $\mathrm{NO}_{2}$ during the night indicates the production of $\mathrm{O}_{3}$ from the photolysis of $\mathrm{NO}_{2}$ from the flash of fire bursting. As the emission is mainly confined in the visible and near infra-red region, we judge that $\mathrm{O}_{3}$ production was via photolysis of $\mathrm{NO}_{2}$ around $420 \mathrm{~nm}$. The excess $\mathrm{NO}_{2}$ required for the enhancement of $\mathrm{O}_{3}$ was formed from some other species produced during fire bursting.

\subsection{Rate of Change of $\mathrm{O}_{3}$ on Diurnal Scale during Fire Bursting}

Figure 8 shows the diurnal variation of the rate of change of $\mathrm{O}_{3}$ with respect to time $\left[\mathrm{d}\left(\mathrm{O}_{3}\right) / \mathrm{dt}\right]$ for pre-, post-, and Vishu days. Surprisingly, it is observed that the rate of increase of $\mathrm{O}_{3}$ during the early morning hours of Vishu day from 08:00 to 10:00 is moderately low in the four consecutive years. This is because of the reduced rate of photolysis caused by scattering of sun light by particulate matter in a highly polluted atmosphere. The rate of increase was $2.58 \mu \mathrm{gm}^{3}$ and $4.96 \mu \mathrm{gm}^{3}$ at 09:00 and 10:00, respectively, on the Vishu day, while it was $3.64 \mu^{2} \mathrm{gm}^{3}$ and $3.82 \mu \mathrm{gm}^{3}$, respectively, on pre-Vishu days and $3.02 \mu \mathrm{gm}^{3}$ and $3.78 \mu \mathrm{gm}^{3}$, respectively, on post-Vishu days. The rate of change of $\mathrm{O}_{3}$ was found to be high in the noon when the particles were dispersed through convection from the surface and the enhanced photochemical reactions in the presence high concentrations of $\mathrm{NO}_{2}$ and VOCs. The observed rate of change of $\mathrm{O}_{3}$ at noon time 12:00 on Vishu days was $9.58 \mu \mathrm{gm}^{3}$. For pre-Vishu days, it was $6.05 \mu \mathrm{gm}^{3}$ and $5.22 \mu \mathrm{gm}^{3}$ and for post-Vishu days, it was $5.79 \mu \mathrm{gm}^{3}$ and $6.98 \mu \mathrm{gm}^{3}$, respectively.

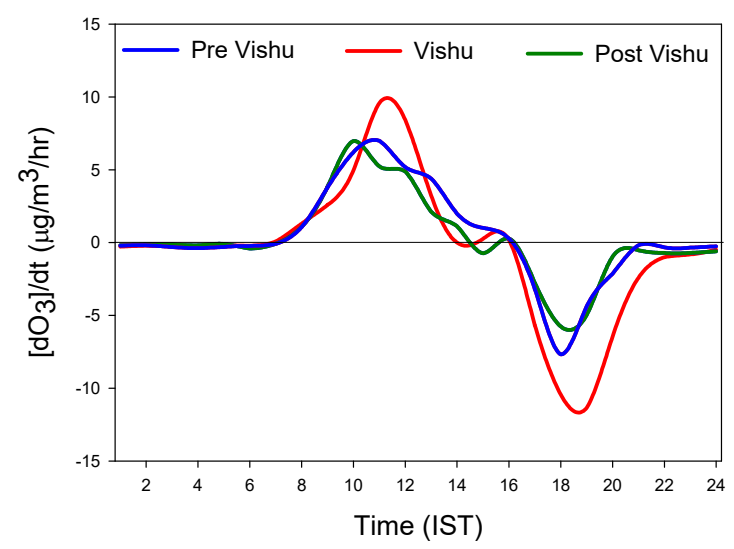

Figure 8. Rate of change of $\mathrm{O}_{3}$ on Vishu and control days.

Figure 9 shows a magnified view of the rate of increase in $\mathrm{O}_{3}$ observed compared with the rate on control days. 


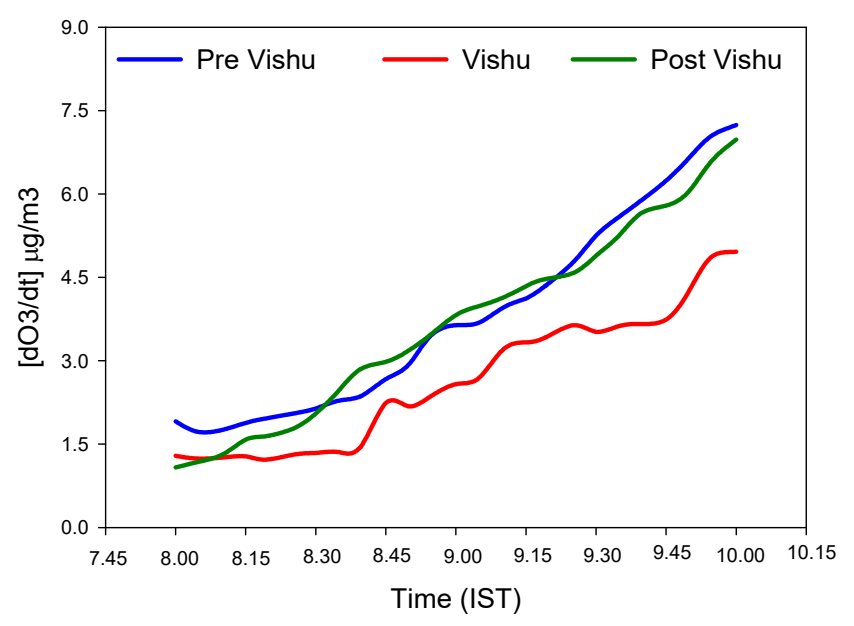

Figure 9. A magnified view of the rate of increase of ozone in early morning.

The slow growth of $\mathrm{O}_{3}$ during the early morning of Vishu day is mainly attributed to the extinction of sunlight by the heavy loading of dust and smoke even in a rich $\mathrm{NO}_{2}$ environment confined in a shallow boundary layer. After 11:00, the smoke is dispersed through convection, which results in an increased rate of increment of $\mathrm{O}_{3}$ until noon. Thus, this observation reveals the slow $\mathrm{O}_{3}$ production rate in a polluted environment as well. The value of $\left[\mathrm{d}\left(\mathrm{O}_{3}\right) / \mathrm{dt}\right]$ is almost zero from 14:00 to 15:00 on both Vishu and control days and it is found to be almost steady during the night time. At midnight, $\mathrm{O}_{3}$ loss caused surface deposition. It is notable that the lapse rate of surface $\mathrm{O}_{3}$ in the evening was not very distinct compared with the morning production rate.

\subsection{Correlation between $P M_{10}$ and Trace Gases}

$\mathrm{PM}_{10}$ can modify the energy balance of the atmosphere through scattering and absorption of light. Characterised by a very large surface area, $\mathrm{PM}_{10}$ influences the tropospheric trace gas chemistry by its surface reaction, causing a photolysis rate reduction, thus inhibiting $\mathrm{O}_{3}$ production [79-82]. A global modelling study by Bauer et al. [83] suggested that during the year 2000, the global tropospheric ozone decreased by $5 \%$. This could be the result of the heterogeneous reactions on dust particulate matter aerosol. In the Mediterranean region, Bonasoni [84] reported a sharp decline in surface $\mathrm{O}_{3}$ concentration present in the atmosphere when the air mass contains coarse particles coming from North Africa. By analysing the data of urban air pollutants at Nanjing, East China, Jia et al. [85] observed an inverse relation between $\mathrm{PM}_{2.5}$ and $\mathrm{O}_{3}$ with the confidence level of $99 \%$.

Figure 10a shows the correlation between $\mathrm{PM}_{10}$ and $\mathrm{O}_{3}$ in the study period. It was found that $\mathrm{PM}_{10}$ and $\mathrm{O}_{3}$ show a linear relation with a negative correlation coefficient of -0.72 . The diverse reactions on aerosols can play a major role in determining the chemical composition of the atmosphere [86]. The enhanced $\mathrm{PM}_{10}$ levels suppressed the solar insolation, which could weaken $\mathrm{O}_{3}$ production. Under the high PM level exceeding $150 \mu \mathrm{g} / \mathrm{m}^{3}$, the surface $\mathrm{O}_{3}$ concentration dropped to $20.5 \mu \mathrm{g} / \mathrm{m}^{3}$ at noon time, leading to a negative correlation between $\mathrm{PM}$ and $\mathrm{O}_{3}$. Being denser than air, $\mathrm{NO}_{2}$ precipitates in the lower layers of the atmosphere [87]. $\mathrm{NO}_{2}$ has a substantial impact on $\mathrm{PM}_{10}$ through their atmospheric oxidation to aerosol nitrate and the $\mathrm{CO}$ formed from the oxidation of VOCs [88]. Figure $10 \mathrm{~b}$ shows the correlation between $\mathrm{PM}_{10}$ and $\mathrm{NO}_{2}$. There is a linear relation with a strong positive correlation coefficient of 0.86 , indicating that the rising trend of $\mathrm{PM}_{10}$ is better related to the increase in $\mathrm{NO}_{2}$. Statistical analysis (Student's $t$-test) was conducted and the correlation coefficient was found to be significant at the $92 \%$ confidence level. 

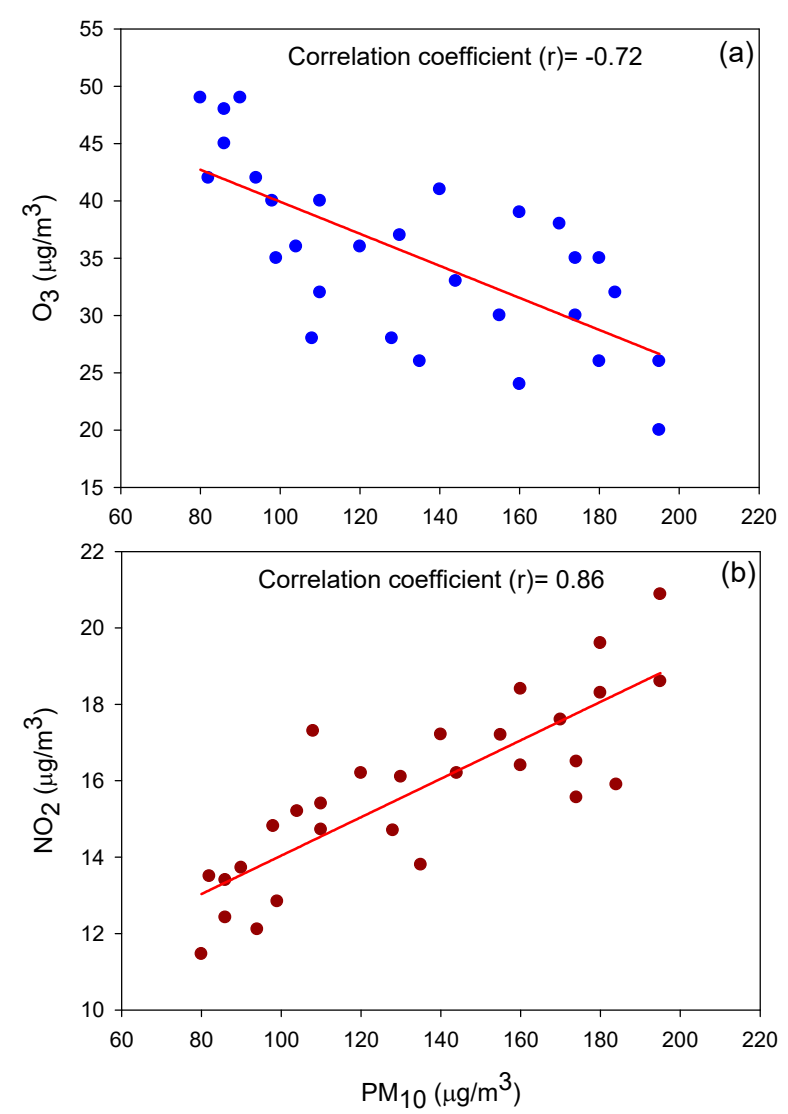

Figure 10. Correlation between (a) $\mathrm{PM}_{10}$ and $\mathrm{O}_{3}$ and (b) $\mathrm{PM}_{10}$ and $\mathrm{NO}_{2}$.

\subsection{Model Simulation for $\mathrm{JNO}_{2}$}

Model calculated variations of $\mathrm{JNO}_{2}$ for the normal and Vishu episodes for the year 2018 are shown in Figure 11. It is seen that as the fireworks begin, $\mathrm{JNO}_{2}$ started to increase during the night and early morning from its normal value. Modeled $\mathrm{NO}_{2}$ levels increased from its value of $\sim 10.2 \mathrm{ppbv}$ just after the fire bursting to $\sim 17.6 \mathrm{ppbv}$ (increase of $73 \%$ ) on 14 April (evening spell) and from $\sim 4.9 \mathrm{ppbv}$ just after the fire bursting to $10.2 \mathrm{ppbv}(109 \%)$ on 15 April near (early morning spell) with the net upsurge in $\mathrm{O}_{3}$ levels of $7.4 \mathrm{ppbv}$ and $5.3 \mathrm{ppbv}$, respectively. This model estimated increase in $\mathrm{O}_{3}$ during the two spell is in good agreement with the observed increase of $7.1 \mathrm{ppbv}$ and $5.8 \mathrm{ppbv}$, respectively. Further, there exists a positive linear correlation coefficient $(\mathrm{r}=0.85)$ between the observed and model simulated $\mathrm{O}_{3}$.

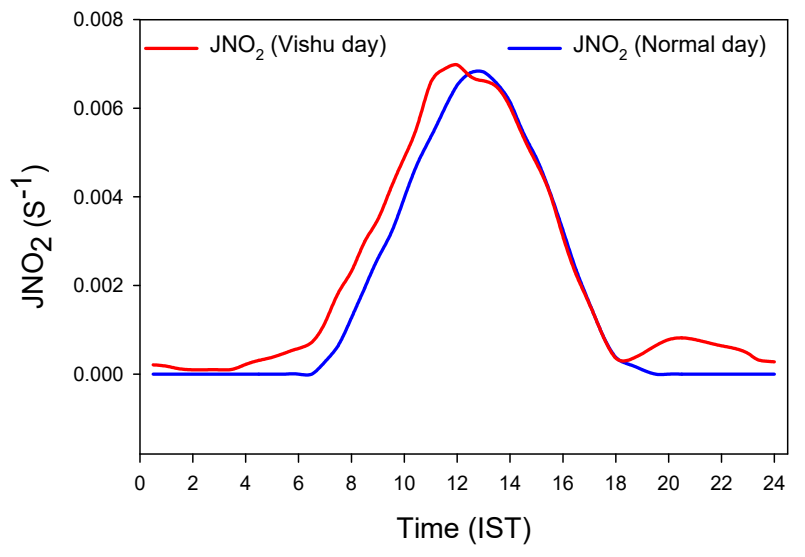

Figure 11. Calculated and model simulated $\mathrm{JNO}_{2}$ variation during normal days and Vishu day for the year 2018 . 


\subsection{Model Simulation for $\mathrm{O}_{3}$}

The initial and background mixing ratios of $\mathrm{O}_{3}, \mathrm{CO}, \mathrm{CH}_{4}, \mathrm{C}_{3} \mathrm{H}_{6}$, i-butane, isoprene, and $\mathrm{CH}_{2} \mathrm{O}$ are set to $40 \mathrm{ppbv}, 480 \mathrm{ppbv}, 1.8 \mathrm{ppmv}, 5 \mathrm{ppbv}, 4 \mathrm{ppbv}, 5 \mathrm{ppbv}$, and 5 ppbv, respectively. The background $\mathrm{O}_{3}$ value of $40 \mathrm{ppbv}$ represents the average daytime (11:00-16:00 IST) $\mathrm{O}_{3}$ mixing ratio observed at Kannur. The observations of $\mathrm{NO}$ and $\mathrm{NO}_{2}$ are available and other species are not available at this site, and hence their values are set to represent a typical rural environment. Diurnal variation in boundary layer height $(0.5-2.0 \mathrm{Km})$ is also provided as an input to the model. The effect of fire bursting on the production of $\mathrm{O}_{3}$ during the night time is simulated using the option of non-cloudy sky fraction available in the model. For the simulation, the time evolution of solar anonymity is introduced in the model, while all other input parameters were kept to their values of normal simulation. This allows examining the impact of fire bursting on the photochemical $\mathrm{O}_{3}$ production. The chemical production of $\mathrm{O}_{3}$ in the troposphere involves the photolysis of $\mathrm{NO}_{2}$ molecules. Generally, $\mathrm{NO}_{2}$ is produced by conversion of $\mathrm{NO}$ into $\mathrm{NO}_{2}$ via peroxy radicals $\left(\mathrm{HO}_{2}, \mathrm{RO}_{2}\right)$. Therefore, the photo dissociation of $\mathrm{NO}_{2}$ is the key reaction for $\mathrm{O}_{3}$ production in the troposphere. The skiving in solar radiation during the night time will significantly affect this photolysis reaction. Variations in $\mathrm{O}_{3}$ for pre-, post-, and Vishu day as well as model simulations for the year 2018 are shown in Figure 12. B1, E1 and B2, E2 in the figure represents the beginning and end of fireworks during the first spell (14 April evening) and second spell (15 April morning), respectively.

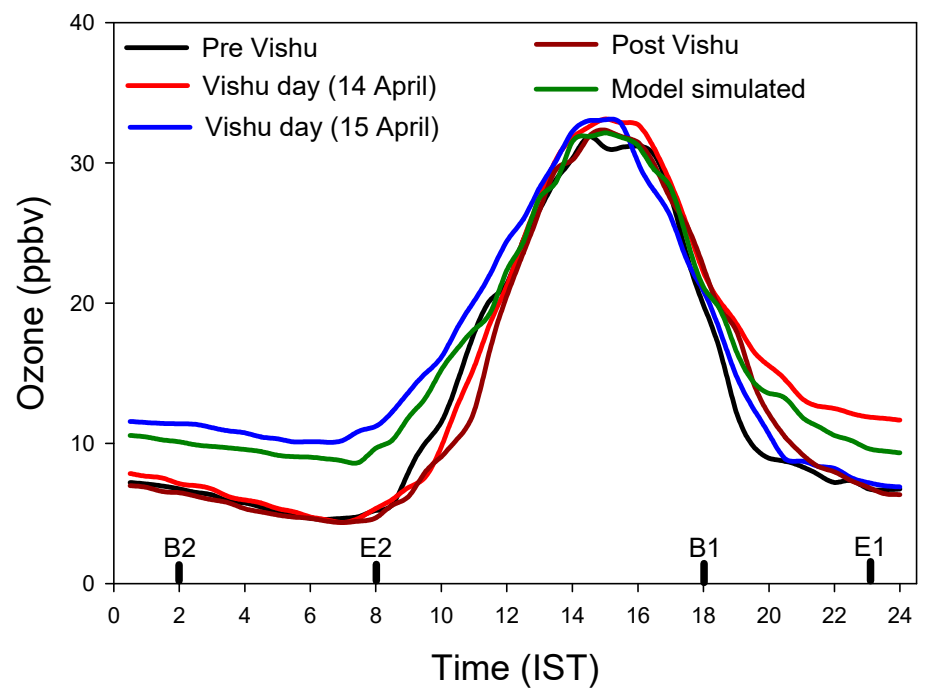

Figure 12. Observed and model simulated $\mathrm{O}_{3}$ variation during pre-, post-, and Vishu day for the year 2018.

It can be seen that the model has successfully captured the daytime $\mathrm{O}_{3}$ build up on normal days, which is mainly as a result of the photochemistry involving the precursor gases. For the Vishu episode, $\mathrm{O}_{3}$ levels start increasing just the beginning of the fire bursting and attains high levels during the early morning and evening hours. The model simulation for the fire bursting episode follows the normal variation until the fire bursting begins. The model simulated $\mathrm{O}_{3}$ shows a continuous increase from the beginning of fire bursting during two phase viz. early morning and evening. As the solar intensity reaches a maximum during noon time, $\mathrm{O}_{3}$ levels show a normal value. Even after the end of fire bursting, $\mathrm{O}_{3}$ levels are seen to be quite a bit higher for few hours than those during normal conditions. This could be because of the gain and faster photochemical production of $\mathrm{O}_{3}$ during the fire bursting.

The modeled $\mathrm{O}_{3}$ levels increased from their value of $\sim 10.2 \mathrm{ppbv}$ just after the fire bursting to $\sim 17.6 \mathrm{ppbv}$ (increase of $73 \%$ ) on 14 April (evening spell) and from $\sim 4.9 \mathrm{ppbv}$ just after the fire bursting to $\sim 10.2 \mathrm{ppbv}(109 \%)$ on 15 April near (early morning spell) with the net upsurge in $\mathrm{O}_{3}$ levels of $7.4 \mathrm{ppbv}$ and $5.3 \mathrm{ppbv}$, respectively. This model estimated increase in $\mathrm{O}_{3}$ during the two spell is in 
good agreement with the observed increase of $7.1 \mathrm{ppbv}$ and $5.8 \mathrm{ppbv}$, respectively, during the two spells of fire bursting episodes in 2018.

\subsection{Correlation of Particulate Matter and Meteorological Parameters}

Meteorological parameters such as wind speed, wind direction, temperature, and relative humidity play an important role in the concentration and transportation of the pollutants in the atmosphere. The importance of meteorological parameters in constraining the atmospheric processes of dilution, transformation, transport, and removal of pollutants has been extensively reported by several authors [89-91]. While analysing the meteorological parameters recorded hourly over the observational site, we found that the atmospheric conditions remained unaltered in respect to temperature, humidity, and wind speed. During the observational days, the sky remained clear with a few scattered clouds. Because the wind speed remains unaltered, the transport of pollutants by advection is likely not affected during fireworks. Thus, the $\mathrm{O}_{3}$ formation can be attributed to the chemistry imparted by the fireworks in the atmosphere. The levels of $\mathrm{PM}_{10}$ depend not only on their emission sources, but also on meteorological parameters such as wind, temperature, relative humidity, atmospheric pressure, and boundary layer height [92].

In our observation, we have found that $\mathrm{PM}_{10}$ is positively correlated with temperature $(\mathrm{r}=0.52)$ and wind speed $(\mathrm{r}=0.58)$, and negatively correlated with relative humidity $(\mathrm{r}=-0.42)$. High wind speed and temperature play a vital role in the dispersion and transportation of air pollutants from one place to another, ranging from local to regional or global scale, thus encouraging vertical and horizontal movement of the particles [93]. Charron and Harrison [94] reported that ultrafine particles had higher concentrations during the rainy periods, which might show that relative humidity has different effects on the concentrations of fine and course particles. This is probably the reason that relative humidity showed a stronger negative correlation with $\mathrm{PM}_{10}$.

\subsection{Air Quality Index during Vishu}

The air pollution index is considered to be the standard tool to represent day-to-day changes in air quality. It transforms complex air quality data of various pollutants into a single value nomenclature. This index was introduced by the U.S. Environmental Protection Agency to estimate the levels of pollution in the ambient atmosphere. Accordingly, the observed concentrations of the $\mathrm{O}_{3}, \mathrm{NO}_{2}$, and $\mathrm{PM}_{10}$ were converted into an air quality index using the standard value and rating scale (up to 25: clean air, 26-50: light air pollution, 51-75: moderate air pollution, 76-100: heavy air pollution, and above 100: severe air pollution) given by Nasir and Brahmaiah [95]. Each of these categories is decided based on ambient concentration values of air pollutants and their likely health impacts. The AQI was calculated by the following formula:

$$
\mathrm{AQI}=\frac{\text { Observed mean concentration of a pollutant }}{\text { Standard for the respective pollutant }} \times 100
$$

Figure 13 represents the temporal variation of air quality index during control days and Vishu day in the study area.

The highest index of 81 (heavy air pollution) was observed on 15 April 2017 during the day time, followed by 70 (moderate air pollution) on the 14 April night. The deterioration of air quality during the night time is a serious concern because of the trapping of pollutants in the shallow boundary layer and low convective activities from the ground. Further, the air pollution level is growing over this location in Kerala's coastal belt with high humidity in the summer season, in which Vishu is celebrated. 


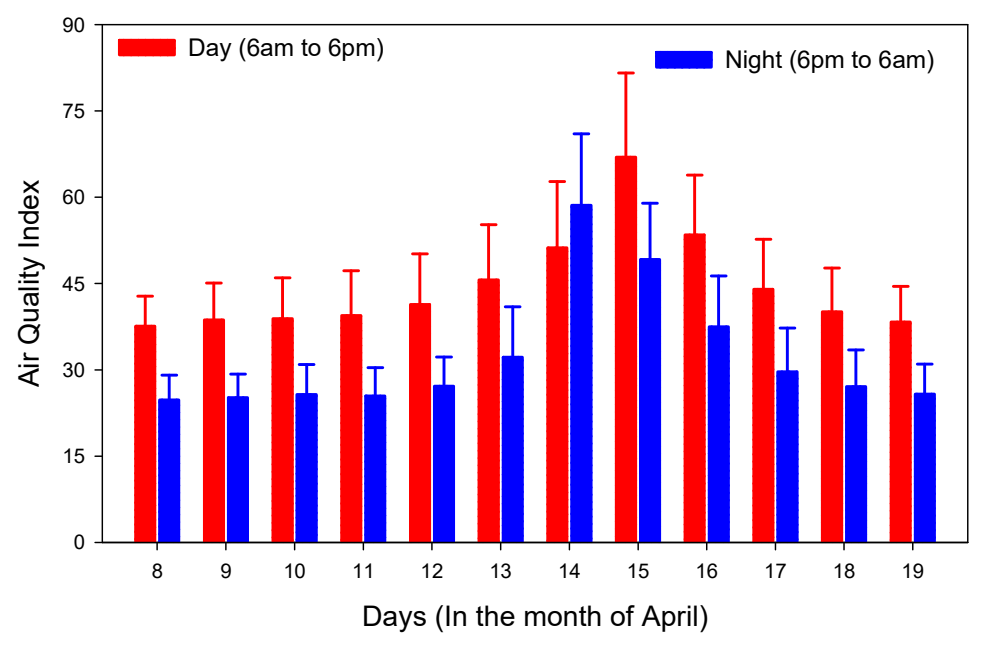

Figure 13. Air quality index for pre-, post-, and Vishu episode.

\section{Conclusions}

Concentrations of air pollutants such as $\mathrm{PM}_{10}, \mathrm{O}_{3}$, and $\mathrm{NO}_{2}$ were monitored for four consecutive years of the celebration of Vishu in Kannur, India, for assessing the air quality impacts of fireworks. The concentrations of air pollutants increased steadily to the peak on fire bursting events and declined thereafter. A quantitative analysis of $\mathrm{O}_{3}, \mathrm{NO}_{2}, \mathrm{PM}_{10}$, and trace metals revealed elevated concentrations of these pollutants in the atmosphere. The concentration of metals in $\mathrm{PM}_{10}$ was found to increase in fireworks on Vishu day and the percentage of increase varied from metal to metal. The increase in AOD was found to be higher at the lower wavelength region, which reveals the presence of a significant amount of fine mode particles in the ambient air. The observed $\mathrm{O}_{3}$ concentration showed an average increase of $69 \%$ on 14 April and $113 \%$ on 15 April of 2018 and $\mathrm{NO}_{2}$ concentration showed an increase of $103 \%$ on 14 April and $85 \%$ on 15 April of 2018 Vishu day compared with control days. These changes in $\mathrm{O}_{3}$ and $\mathrm{NO}_{2}$ mixing ratios could be associated with the enhanced $\mathrm{NO}_{2}$ photolysis rates, as indicated by the model simulation.

The model estimated increase in $\mathrm{O}_{3}$ production of $73 \%$ on 14 April and $109 \%$ on 15 April is in agreement with the observed production of $69 \%$ on 14 April and $113 \%$ on 15 April during the fireworks. The model as well as observations reveal that the increased photochemical production of $\mathrm{NO}_{2}$ is responsible for the observed higher $\mathrm{O}_{3}$ during fireworks at Kannur. The rate of production of $\mathrm{O}_{3}$ in the early morning hours was quite slow on Vishu day, during which the air pollution was much higher, which was consistently observed during the study periods. $\mathrm{PM}_{10}$ and $\mathrm{O}_{3}$ show a linear relation with a strong negative correlation coefficient $(-0.72)$ and $\mathrm{PM}_{10}$ and $\mathrm{NO}_{2}$ show a linear relation with strong positive correlation coefficient of 0.86 , which indicates the rising trend of $\mathrm{PM}_{10}$ is better related to the increase in $\mathrm{NO}_{2}$. A meteorological analysis reveals that $\mathrm{PM}_{10}$ is positively correlated with temperature $(\mathrm{r}=0.52)$ and wind speed $(\mathrm{r}=0.58)$ and negatively correlated with relative humidity $(\mathrm{r}=-0.42)$.

The air quality index estimated from different pollutants shows the highest index value of 81 , indicating heavy air pollution in Kannur on Vishu day. It is also confirmed that the yearly air pollution is growing in Kannur, by which the air quality index value has increased gradually from 2015 to 2018 . This work has been initiated since 2009 and is still continuing, the changes in air quality over this location have a social impact. Our previous publications have had a media impact, by which the Central Pollution Control Board (CPCB) of India conducted a campaign in this region and several health monitoring camps were organized to retrieve the changes in air quality. It has been further observed that the amount and duration of fireworks used for celebration have been increasing in the last few years and continuation of this would significantly increase health hazards at the expense of joyous celebrations in this region. 
Author Contributions: Data curation, R.C.; Investigation, N.T. and S.K.M.; Project administration, S.K.M.; Resources, S.K.M. and B.M.; Supervision, S.K.M. and V.K.

Funding: This research was funded by Indian Space Research Organization -Geosphere Biosphere Programme (ISRO-GBP) through their Atmospheric Chemistry-Transport and Modelling Project (AT-CTM) for the long term study of surface $\mathrm{O}_{3}$ and its precursor gases over Kannur and Kerala State Council for Science, Technology and Environment (KSCSTE) for the study of aerosols over Kannur region.

Acknowledgments: The authors acknowledge the support of the ISRO-GBP (AT-CTM) Project Director Shyam Lal of Physical Research Laboratory, India, throughout this program. We highly acknowledge Sasha Madronich and coworkers for development of NCAR Master Mechanism box model. Valsaraj acknowledges the financial support for publication charges provided from Charles \& Hilda Roddey Distinguished Professorship in Chemical Engineering at LSU. Authors acknowledge the assistance from Syama Pooja, Sree Krishna College Guruvayur for her support in editing this manuscript. One of the authors, Resmi expresses her gratitude to the Principal, Head of the Department of Physics and other authorities of Erode Arts and Science College, Tamil Nadu for providing necessary facilities and constant encouragement. Suggestions and comments from the anonymous reviewers are greatly appreciated.

Conflicts of Interest: The authors declare no conflict of interest.

\section{References}

1. Molina, M.J.; Molina, L.T. Critical Review: Megacities and atmospheric pollution. J. Air Waste Manag. 2004, 54, 644-680. [CrossRef]

2. Chan, K.C.; Yao, X. Air pollution in mega cities in China. Atmos. Environ. 2008, 42, 1-42. [CrossRef]

3. Agus, E.L.; Lingard, J.J.N.; Tomlin, A.S. Suppression of nucleation mode particles by biomass burning in an urban environment: A case study. J. Environ. Monit. 2008, 10, 979-988. [CrossRef]

4. Kwasny, F.; Madl, P.; Hofmann, W. Comparing lung deposition of ultrafine particles caused by fireworks and traffic. J. Aerosol Sci. 2009, 29, 5-6.

5. Burkart, J.; Steiner, G.; Reischl, G.; Moshammer, H.; Neuberger, M.; Hitzenberger, R. Characterizing the performance of two optical particle counters (Grimm OPC1.108 and OPC1.109) under urban aerosol conditions. J. Aerosol Sci. 2010, 41, 953-962. [CrossRef] [PubMed]

6. Joly, A.; Smargiassi, A.; Kosatsky, T.; Fournier, M.; Dabek-Zlotorzynska, E.; Celo, V.; Mathieu, D.; Servranckx, R.; D'amours, R.; Malo, A.; et al. Characterisation of particulate during fireworks displays. Atmos. Environ. 2010, 44, 4325-4329. [CrossRef]

7. Nastos, P.T.; Paliatsos, A.G.; Anthracopoulos, M.B.; Roma, E.S.; Kostas, N. Outdoor particulate matter and childhood asthma admissions in Athens, Greece: A time series study. Environ. Health 2010, 9, 45. [CrossRef] [PubMed]

8. Singh, D.P.; Gadi, R.; Mandal, T.K.; Dixit, C.K.; Singh, K.; Saud, T.; Singh, N.; Gupta, P.K. Study of temporal variation in ambient air quality during Diwali festival in India. Environ. Monit. Assess. 2010, 169, 1-13. [CrossRef] [PubMed]

9. Samoli, E.; Nastos, P.T.; Paliatsos, A.G.; Katsouyanni, K.; Priftis, K.N. Acute effects of air pollution on paediatric asthma exacerbation: Evidence of association and effect modification. Environ. Res. 2011, 111, 418-424. [CrossRef]

10. Licudine, J.A.; Yee, H.; Chang, W.L.; Whelen, A.C. Hazardous metals in ambient air due to New Year fireworks during 2004-2011 celebrations in Pearl City, Hawaii. Public Health Rep. 2012, 127, 440. [CrossRef]

11. Bapna, M.; Raman, R.S.; Ramachandran, S.; Rajesh, T.A. Airborne black carbon concentrations over an urban region in western India, temporal variability, effects of meteorology and source regions. Environ. Sci. Pollut. Res. 2013, 20, 1617-1631. [CrossRef] [PubMed]

12. Bhuyan, P.K.; Bharali, C.; Pathak, B.; Kalita, G. The role of precursor gases and meteorology on temporal evolution of $\mathrm{O}_{3}$ at a tropical location in northeast India. Environ. Sci. Pollut. Res. 2014, 21, 6696-6713. [CrossRef] [PubMed]

13. Tian, Y.Z.; Wang, J.; Peng, X.; Shi, G.L.; Feng, Y.C. Estimation of direct and indirect impacts of fireworks on the physicochemical characteristics of atmospheric fine and coarse particles. Atmos. Chem. Phys. Discuss. 2014, 14, 11075-11101. [CrossRef]

14. Shon, Z.H.; Jeong, J.H.; Kim, Y.K. Characteristics of atmospheric metalliferous particles during large-scale fireworks in Korea. Adv. Meteorol. 2015, 2015, 3-13. [CrossRef] 
15. Xu, J.; Ding, G.A.; Yan, P.; Zhang, J.C.; Wang, S.F.; Meng, Z.Y.; Zhang, Y.M.; Liu, Y.C.; Zhang, X.L. Effect of firecracker setting-off on the fine particle pollution in Beijing downtown areas. J. Saf. Environ. 2006, 5, 79-82.

16. Agrawal, A.; Upadhyay, V.K.; Sachdeva, K. Study of aerosol behavior on the basis of morphological characteristics during festival events in India. Atmos. Environ. 2011, 45, 3640-3644. [CrossRef]

17. Crespo, J.; Yubero, E.; Nicolás, J.F.; Lucarelli, F.; Nava, S.; Chiari, M.; Calzolai, J. High-time Resolution and Size-segregated Elemental Composition in High intensity Pyrotechnic Exposures. J. Hazard. Mater. 2012, 241, 82-91. [CrossRef] [PubMed]

18. Azhagurajan, A.; Selvakumar, N.; Suresh, A. Environment friendly fireworks manufacturing using nano scale flash powder. J. Sci. Ind. Res. 2014, 73, 479-484.

19. Lin, C.C.; Huang, K.L.; Chen, H.L.; Tsai, J.H.; Chiu, Y.P.; Lee, J.T.; Chen, S.J. Influences of Beehive Firework Displays on Ambient Fine Particles during the Lantern Festival in the YanShuei Area of Southern Taiwan. Aerosol Air Qual. Res. 2014, 14, 1998-2009. [CrossRef]

20. Caballero, S.; Galindo, N.; Castañer, R.; Giménez, J.; Crespo, J. Real-Time Measurements of Ozone and UV Radiation during Pyrotechnic Displays. Aerosol Air Qual. Res. 2015, 15, 2150-2157. [CrossRef]

21. Kulshrestha, U.C.; Rao, N.T.; Azhaguvel, S.; Kulshrestha, M.J. Emissions and accumulation of metals in the atmosphere due to crackers and sparkles during Diwali festival in India. Atmos. Environ. 2004, 38, 4421-4425. [CrossRef]

22. Cinzia, P.; Suresh, T.; Maria, C.; Stefano, D.T.; Elena, R.; Silvia, C. Chemical characterization of atmospheric PM in Delhi, India during different periods of the year including Diwali festival. Atmos. Pollut. Res. 2011, 2, 418-427.

23. Kankal, S.B.; Gaikwad, R.W. Studies on noise and air quality monitoring at Shirdi (Maharashtra), India. Adv. Appl. Sci. Res. 2011, 2, 63-75.

24. Pachauri, T.; Singla, V.; Satsangi, A.; Lakhani, A.; Kumari, K.M. Characterization of major pollution events (dust, haze, and two festival events) at Agra, India. Environ. Sci. Pollut. Res. 2013, 20, 5737-5752. [CrossRef] [PubMed]

25. Prakash, D.; Payra, S.; Verma, S.; Soni, M. Aerosol particle behavior during Dust Storm and Diwali over an urban location in north western India. Nat. Hazards 2013, 69, 1767-1779. [CrossRef]

26. Vyas, B.M.; Saraswat, V. Studies of atmospheric aerosol's parameters during pre diwali to post diwali festival period over Indian semi-arid station at, Udaipur. Appl. Phys. Res. 2012, 4, 40-55. [CrossRef]

27. Singh, B.P.; Srivastava, A.K.; Tiwari, S.; Singh, S.; Singh, R.K.; Bisht, D.S.; Lal, D.M.; Singh, A.K.; Mall, R.K.; Srivastava, M.K. Radiative impact of fireworks at a tropical Indian location: A case study. Adv. Meteorol. 2014, 2014, 197072. [CrossRef]

28. Smith, R.M.; Vu, D.D. Changes in forced expiratory flow due to air pollution from fireworks. Environ. Res. 1975, 9, 321-331. [CrossRef]

29. Bach, W.; Dickinson, L.; Weiner, B.; Costello, G. Some adverse health effects due to air pollution from fireworks. Hawaii Med. J. 1972, 31, 459-465. [PubMed]

30. Vecchi, R.; Bernardoni, V.; Cricchio, D.; Alessandro, A.D.; Fermo, P.; Lucarelli, F.; Nava, S.; Piazzalunga, A.; Vallia, G. The impact of fireworks on air borne particles. Atmos. Environ. 2008, 42, 1121-1132. [CrossRef]

31. Moreno, T.; Querol, X.; Alastuey, A.; Amato, F.; Peya, J.; Pandolfi, M.; Kuenzli, N.; Bouso, L.; Rivera, M.; Gibbons, W. Effect of fireworks events on urban background trace metal aerosol concentrations: Is the cocktail worth the show. J. Hazard. Mater. 2010, 183, 945-949. [CrossRef]

32. Camilleri, R.; Vella, A.J. Effect of fireworks on ambient air quality in Malta. Atmos. Environ. 2010, 44, 4521-4527. [CrossRef]

33. Drewnick, F.; Hings, S.S.; Curtius, J.; Eerdekens, G.; Williams, J. Measurement of fine particulate and gas-phase species during the New Year's fireworks 2005 in Mainz, Germany. Atmos. Environ. 2006, 40, 4316-4327. [CrossRef]

34. Godri, K.J.; Green, D.C.; Fuller, G.W.; Dall'Osto, M.; Beddows, D.C.; Kelly, F.J.; Harrison, R.M.; Mudway, I.S. Particulate oxidative burden associated with firework activity. Environ. Sci. Technol. 2010, 1, 8295-8301. [CrossRef]

35. Croteau, G.; Dills, R.; Beaudreau, M.; Davis, M. Emission factors and exposures from ground-level pyrotechnics. Atmos. Environ. 2010, 44, 3295-3303. [CrossRef]

36. Reka, S.; Abhilash, S.P.; Neha, S.P.; Sunil, K.P.; Beig, G. Sensitivity of online coupled model to extreme pollution event over a mega city Delhi. Atmos. Pollut. Res. 2016, 7, 25-30. 
37. Thakur, B.; Chakraborty, S.; Debsarka, R.A.; Chakrabarty, S.; Srivastava, R.C. Air pollution from fireworks during festival of lights (Deepawali) in Howrah, India-A case study. Atmósfera 2010, 23, 347-365.

38. Tiwari, S.; Chate, D.M.; Srivastava, M.K. Statistical evaluation of $\mathrm{PM}_{10}$ and distribution of PM, PM 2.5 , and $\mathrm{PM}_{10}$ in ambient air due to extreme fireworks episodes (Deepawali festivals) in megacity Delhi. Nat. Hazards 2012, 61, 521-531. [CrossRef]

39. Chatterjee, A.; Sarkar, C.; Adak, A.; Mukherjee, U.; Ghosh, S.K.; Raha, S. Ambient air quality during Diwali Festival over Kolkata-A mega city in India. Aerosol Air Qual. Res. 2013, 13, 1133-1144. [CrossRef]

40. Wang, X.; Bi, X.; Sheng, G.; Fu, J. Hospital indoor $\mathrm{PM}_{10} / \mathrm{PM}_{2.5}$ and associated trace elements in Huangzhou, China. Sci. Total Environ. 2006, 366, 124-135. [CrossRef]

41. Becker, J.M.; Iskandrian, S.; Conkling, J. Fatal and near-fatal asthma in children exposed to fireworks. Ann. Allergy Asthma Immunol. 2000, 85, 512-513. [CrossRef]

42. Bull, M.J.; Agran, P.; Gardner, H.G.; Laraque, D.; Pollack, S.H.; Smith, G.A. Fireworks related injuries to children. Pediatrics 2001, 108, 190-191.

43. Kannan, G.K.; Gupta, M.; Kapoor, J.C. Estimation of gaseous products and particulate matter emission from garden biomass combustion in a simulation fire test chamber. Atmos. Environ. 2004, 38, 6701-6710. [CrossRef]

44. Barman, S.C.; Singh, R.; Negi, M.P.S.; Bhargava, S.K. Ambient air quality of Lucknow City (India) during use of fireworks on Diwali Festival. Environ. Monit. Assess. 2008, 137, 495-504. [CrossRef] [PubMed]

45. Ambade, B.; Ghosh, S. Characterization of $\mathrm{PM}_{10}$ in the ambient air during Deepawali festival of Rajnandgaon District, India. Nat. Hazards 2013, 69, 589-598. [CrossRef]

46. Baranyai, E.; Simon, E.; Braun, M.; Tóthmérész, B.; Posta, J.; Fábián, I. The effect of a fireworks event on the amount and elemental concentration of deposited dust collected in the city of Debrecen, Hungary. Air Qual. Atmos. Health. 2015, 8, 359-365. [CrossRef]

47. Curtis, L.; Rea, W.; Smith-Willis, P.; Fenyves, E.; Pan, Y. Adverse health effects of outdoor air pollutants. Environ. Internsh. 2006, 32, 815-830. [CrossRef]

48. Mandal, P.; Prakash, M.; Bassin, J.K. Impact of Diwali celebrations on urban air and noise quality in Delhi City, India. Environ. Monit. Assess. 2012, 184, 209-215. [CrossRef]

49. Nishanth, T.; Praseed, K.M.; Rathnakaran, K.; Satheesh Kumar, M.K.; Ravi Krishna, R.; Valsaraj, K.T. Atmospheric pollution in a semi-urban, coastal region in India following festival seasons. Atmos. Environ. 2012, 47, 295-306. [CrossRef]

50. Swamy, Y.V.; Sharma, A.R.; Nikhil, G.N.; Venkanna, R.; Chitanya, N.S.K.; Sinha, P.R. The impact assessment of Diwali fireworks emissions on the air quality of a tropical urban site, Hyderabad, India, during three consecutive years. Environ. Monit. Assess. 2013, 185, 7309-7325.

51. Saha, U.; Talukdar, S.; Jana, S.; Maitra, A. Effects of air pollution on meteorological parameters during Deepawali festival over an Indian urban metropolis. Atmos. Environ. 2014, 98, 530-539. [CrossRef]

52. Myriam, T.; Oliver, R.; Dirk, W.; Dietrich, P. Burden of outdoor air pollution in Kerala, India- A first health risk assessment at state level. Int. J. Environ. Res. Public Health 2015, 12, 10602-10619.

53. Josna, J.D.; Kalaiarasan, P.; Akhil, N.G. Air quality study of selected areas in Kerala state. Int. Res. J. Eng. Technol. 2017, 4, 3517-3521.

54. Morys, M.; Mims, F.M.; Hagerup, S.; Anderson, S.E.; Baker, A.; Kia, J.; Walkup, T. Design, calibration, and performance of Microtops II handheld ozone monitor and sun photometer. J. Geophys. Res. 2001, 106, 14573-14582. [CrossRef]

55. Nishanth, T.; Praseed, K.M.; Satheesh Kumar, M.K.; Valsaraj, K.T. Influence of ozone precursors and PM 10 on the variation of surface ozone over Kannur, India. Atmos. Res. 2014, 138, 112-124. [CrossRef]

56. Madronich, S.; Flocke, S. The role of solar radiation in atmospheric chemistry. In Handbook of Environmental Chemistry; Springer: Heidelberg/Berlin, Germany, 1999; Volume 2, pp. 1-26.

57. Flynn, J.; Lefer, B.; Rappengluck, B.; Leuchner, M.; Perna, R.; Dibb, J.; Ziemba, L.; Anderson, C.; Stutz, J.; Brune, W.; et al. Impact of clouds and aerosols on ozone production in Southeast Texas. Atmos. Environ. 2010, 44, 4126-4133. [CrossRef]

58. Gustavo, G.; Palancar Rafael, P.; Fernandez, T.; Beatriz, M. Photolysis rate coefficients calculations from broadband UV-B irradiance: Model-measurement interaction. Atmos. Environ. 2005, 39, 857-866. 
59. Stamnes, K.; Tsay, S.; Wiscombe, W.J.; Jayaweera, K. Numerically stable algorithm for discrete-ordinatemethod radiative transfer in multiple scattering and emitting layered media. Appl. Opt. 1988, 27, 2502-2509. [CrossRef] [PubMed]

60. Demore, W.B. Chemical Kinetics and Photochemical Data for Use in Stratospheric Modelling. California Institute of Technology Pasadena; Jet. Propulsion Laboratory Publications: La Cañada Flintridge, CA, USA, 2000.

61. Atkinson, R. Atmospheric chemistry of VOCs and NOx. Atmos. Environ. 2000, 34, 2063-2101. [CrossRef]

62. Aumont, B.; Madronich, S.; Bey, I.; Tyndall, G.S. Contribution of secondary VOC to the composition of aqueous atmospheric particles: A modelling approach. J. Atmos. Chem. 2000, 35, 59-75. [CrossRef]

63. Madronich, S. Chemical evolution of gaseous air pollutants down-wind of tropical megacities: Mexico City case study. Atmos. Environ. 2006, 40, 6012-6018. [CrossRef]

64. Angstrom, A. On the atmospheric transmission of sun radiation and on dust in the air. Geograf. Ann. 1929, 12, 130-159.

65. Schuster, G.L.; Dovobik, O.; Holben, B.N. Angstrom exponent and bimodal aerosol size distribution. J. Geophys. Res. 2006, 111, D07207. [CrossRef]

66. Eck, T.F.; Holben, B.N.; Reid, J.S.; Dubovik, O.; Neil, N.T.; Kinnie, S. Wavelength dependence of the optical depth of biomass burning, urban and desert dust aerosols. J. Geophys. Res. 1999, 103, 31333-31349. [CrossRef]

67. Kambezidis, H.D.; Tulleken, R.; Amanatidis, G.T.; Paliatsos, A.G.; Asimakopoulos, D.N. Statistical evaluation of selected air pollutants in Athens, Greece. Environmetrics 1995, 6, 349-361. [CrossRef]

68. Junge, C.E. The size distribution and ageing of natural aerosols as determined from electrical and optical measurements in the atmosphere. J. Meteorol. 1955, 12, 13-25. [CrossRef]

69. Kaskaoutis, D.G.; Kambezidis, H.D. Investigation on the wavelength dependence of the aerosol optical depth in Athens area. Q. J. R. Meteorol. Soc. 2006, 132, 2217-2234. [CrossRef]

70. O'Neill, N.T.; Dubovic, O.; Eck, T.F. Modified Angstrom exponent for the characterization of sub micrometre aerosols. Appl. Opt. 2001, 40, 2368-2375. [CrossRef]

71. Eck, T.F.; Holben, B.N.; Dubovic, O.; Smirnov, A.; Slutsker, I.; Lobert, J.M.; Ramanathan, V. Column-integrated aerosol optical properties over the Maldives during the northeast monsoon for 1998-2000. J. Geophys. Res. 2001, 106, 28555-28566. [CrossRef]

72. Christopher, S.A.; Wang, J.; Ji, Q.; Tsay, S. Estimation of diurnal shortwave dust aerosol radiative forcing during PRIDE. J. Geophys. Res. 2003, 108, 8596. [CrossRef]

73. Ogunjobi, K.O.; He, Z.; Kim, K.W.; Kim, Y.J. Aerosol optical depth during episodes of Asian dust storms and biomass burning at Kwangju, South Korea. Atmos. Environ. 2004, 38, 1313-1323. [CrossRef]

74. Ramachandran, S. Spectral aerosol optical characteristics during the northeast monsoon over the Arabian Sea and the tropical Indian Ocean: Angstrom parameters and anthropogenic influence. J. Geophys. Res. 2004, 109, D19208. [CrossRef]

75. Lal, S.; Venkataramani, S.; Naja, M.; Kuniyal, C.J.; Mandal, T.K.; Bhuyan, P.K.; Kumari, K.M.; Tripathi, S.M.; Sarkar, U.; Das, T.; et al. Loss of crop yields in India due to surface ozone: An estimation based on a network of observations. Environ. Sci. Pollut. Res. 2017, 24, 20972-20981. [CrossRef] [PubMed]

76. Attri, A.K.; Kumar, U.; Jain, V.K. Formation of ozone by fireworks. Nature 2001, 411, 1015. [CrossRef] [PubMed]

77. Ravindra, K.; Mor, S.; Kaushik, C.P. Short-term variation in air quality associated with firework events: A case study. J. Environ. Monit. 2003, 5, 260-264. [CrossRef]

78. Wang, Y.; Zhuang, G.; Xu, C.; An, Z. The air pollution caused by the burning of fireworks during the lantern festival in Beijing. Atmos. Environ. 2007, 41, 417-431. [CrossRef]

79. Dentener, F.J.; Crutzen, P. Reaction of $\mathrm{N}_{2} \mathrm{O}_{5}$ on tropospheric aerosol: Impact on the global distributions of $\mathrm{NOx}, \mathrm{O}_{3}$ and $\mathrm{OH}$. J. Geophys. Res. 1993, 98, 7149-7163. [CrossRef]

80. Prospero, J.M.; Schmitt, R.; Cuevas, E.; Savoie, D.L.; Graustein, W.C.; Turekian, K.K.; Volz-Thomas, A.; Diaz, A.; Oltmans, S.J.; Levy, H., II. Temporal variability of summer time ozone and aerosol in the free troposphere over the eastern North Atlantic. Geophys. Res. Lett. 1995, 22, 2925-2928. [CrossRef]

81. Sokolik, I.N.; Toon, O.B. Direct radiative forcing by anthropogenic airborne mineral aerosols. Nature 1996, 381, 681-683. [CrossRef]

82. Dickerson, R.R.; Kondragunta, S.; Stenchikov, G.; Civerolo, K.L.; Doddrige, B.G.; Holben, B.N. The impact of aerosols on solar ultraviolet radiation and photochemical smog. Science 1997, 278, 827-830. [CrossRef] 
83. Bauer, S.E.; Balkanski, Y.; Schulz, M.; Hauglustaine, D.A.; Dentener, F. Global modeling of heterogeneous chemistry on mineral aerosol surfaces: Influence on tropospheric ozone chemistry and comparison to observations. J. Geophys. Res. 2004, 109, D02304. [CrossRef]

84. Bonasoni, P.; Cristofanelli, F.; Calzolari, U.; Bonafè, F.; Evangelisti, S.A.; Zauli, S.S.; van Dingenen, R.; Colombo, T.; Balkanski, Y. Aerosol-ozone correlations during dust transport episodes. Atmos. Chem. Phys. 2004, 4, 1201-1215. [CrossRef]

85. Jia, M.; Zhao, T.; Cheng, X.; Gong, S.; Zhang, X.; Tang, L.; Liu, D.; Wu, X.; Wang, L.; Chen, Y. Inverse Relations of $\mathrm{PM}_{2.5}$ and $\mathrm{O}_{3}$ in Air Compound Pollution between Cold and Hot Seasons over an Urban Area of East China. Atmosphere 2017, 8, 59. [CrossRef]

86. Lei, W.; Zhang, R.; Tie, X.; Hess, P. Chemical characterization of ozone formation in the Houston-Galveston area. J. Geophys. Res. 2004, 109, D12301. [CrossRef]

87. Ruidavets, J.B.; Cournot, M.; Cassadou, S.; Giroux, M.; Meybeck, M.; Ferrieres, J. Ozone air pollution is associated with acute myocardial infarction. Circulation 2005, 111, 563-569. [CrossRef] [PubMed]

88. Wang, Y.; McElroy, M.B.; Munger, J.W.; Hao, J.; Ma, H.; Nielsen, C.P.; Chen, Y. Variations of $\mathrm{O}_{3}$ and $\mathrm{CO}$ in summertime at a rural site near Beijing. Atmos. Chem. Phys. 2008, 8, 6355-6363. [CrossRef]

89. Boubel, R.W.; Fox, D.L.; Turner, D.B.; Stern, A.C. Fundamentals of Air Pollution, 3rd ed.; Academic Press: San Diego, CA, USA, 1993.

90. Dayan, U.; Levy, I. Relationship between synoptic-scale atmospheric circulation and ozone concentrations over Israel. J. Geophys. Res. 2002, 107, 4813. [CrossRef]

91. Pearce, J.; Beringer, J.; Nicholls, N.; Hyndman, R.J.; Uotila, P.; Tapper, N.J. Investigating the influence of synoptic-scale meteorology on air quality using self-organizing maps and generalized additive modeling. Atmos. Environ. 2011, 45, 128-136. [CrossRef]

92. Munir, S.; Habeebullah, T.M.; Seroji, A.R.; Morsy, E.A.; Mohammed, A.M.F.; Saud, W.A.; Esawee, A.L.; Awad, A.H. Modelling particulate matter concentrations in Makkah, applying a statistical modelling approach. Aerosol Air Qual. Res. 2013, 13, 901-910. [CrossRef]

93. Munir, S.; Habeebullah, T.M.; Mohammed, A.M.F.; Morsy, E.A.; Rehan, M.; Ali, K. Analysing PM 2.5 and its Association with $\mathrm{PM}_{10}$ and Meteorology in the Arid Climate of Makkah, Saudi Arabia. Aerosol Air Qual. Res. 2017, 17, 453-464. [CrossRef]

94. Charron, A.; Harrison, R.M. Primary particle formation from vehicle emissions during exhaust dilution in the roadside atmosphere. Atmos. Environ. 2003, 37, 4109-4119. [CrossRef]

95. Nasir, U.P.; Brahmaiah, D. Impact of fireworks on ambient air quality: A case study. Int. J. Environ. Sci. Technol. 2015, 12, 1379-1386. [CrossRef] 